\title{
The Kmif (Kveim-induced macrophage migration inhibition factor) test in sarcoidosis
}

\author{
W. JONES WILliams, E. PIOLI, D. J. JONES, AND M. DigheRO \\ From the Departments of Pathology and Chest Medicine, Welsh National School of Medicine, Cardiff, and \\ the Public Health Laboratory Service, Colindale
}

SYNOPSIS Circulating lymphocytes from 30 patients with sarcoidosis when stimulated in vitro with Kveim-induced macrophage migration factor, the $\mathrm{Kmif}$ test, produced a guinea-pig macrophage migration inhibition factor in 21 of 30 cases $(70 \%)$. In those patients not on steroids the results showed a good correlation with the cutaneous Kveim test. One positive test was found in 16 normal subjects. Our results suggest that the Kmif test may prove a useful rapid alternative to the Kveim test.

Despite the recent controversy as to the specificity of the Kveim test in sarcoidosis (Lancet, 1971; British Medical Journal, 1971 ; Scadding, 1971, 1972), that test remains of considerable value as a diagnostic tool. In consequence, various attempts are being made to develop in-vitro Kveim tests (Bendixen and Søborg, 1969; Hardt and Wanstrup, 1969; Becker, Krull, Deicher, and Kalden, 1972; Topilsky, Siltzbach, Williams, and Glade, 1972). They are based on the work of Søborg and Bendixen (1967), who showed that sensitized lymphocytes, as a result of tuberculin and brucella antigen stimulation, produce a soluble leucocyte/macrophage migration inhibition factor (MIF) which correlates with the results of delayed hypersensitivity skin testing.

We have investigated the in-vitro response of peripheral lymphocytes from patients with sarcoidosis and controls to stimulation by sarcoid (Kveim material) and normal splenic homogenates using guinea-pig macrophages as the indicator cells and refer to this procedure as the Kmif test (Kveiminduced macrophage inhibition factor) (Jones Williams, 1971). It must, however, be understood that there is no firm immunological basis for the test, as the Kveim material contains not one but probably many antigens and no specific migration inhibition factor has yet been isolated from this reaction. The results are compared with the Kveim skin tests and clinical features of the disease.

\section{Materials and Methods}

\section{ANTIGENS}

Both the sarcoid and normal control spleen susReceived for publication 30 August 1972. pensions were prepared by the method of Chase (1961). The sarcoid spleen suspensions used were Colindale type I, K12 (batch no. 14) for the in-vitro test (unphenolized) and for the cutaneous tests, batches 15-19.

PATIENTS WITH SARCOIDOSIS

Thirty subjects, with clinical and radiological features of sarcoidosis, were investigated. All subjects were skin tested with Kveim material, and 25 were positive. The group was composed of 29 Caucasians and one Negro, aged 22-65, 17 females and 13 males. The duration of the disease ranged from three months to 20 years. In 12 patients, on radiological examination, the disease was confined to the hilar lymph nodes. One patient showed clinical evidence of extrathoracic disease and the remainder showed radiological involvement of lung fields with or without hilar lymphadenopathy. Five patients were tested while on steroid therapy, one of whom was tested before and after commencement of treatment. Tuberculin skin testing (10 TU) was negative in 15 of 23 subjects tested.

APPARENTLY HEALTHY CONTROLS

This group consisted of 16 healthy adults aged 20-50, with no clinical evidence of disease. Fourteen were Heaf or Mantoux positive (100 TU) and two were Mantoux negative (10 TU). One of the latter was tested and gave a negative Kveim skin test.

LYMPHOCYTE SEPARATION AND PRODUCTION OF MIGRATION INHIBITION FACTOR

Twenty $\mathrm{ml}$ of venous blood with 200 iu of heparin was mixed with carbonyl iron and methyl cellulose 
and allowed to stand (Dolby, 1969). The lymphocyterich supernatant was washed several times using Eagle's minimal essential medium containing $20 \%$ foetal calf serum and the cells were counted and finally resuspended in the above medium at a concentration of approximately $1 \times 10^{6} \mathrm{cells} / \mathrm{ml}$. The cells were then cultured for 72 hours in $1 \mathrm{ml}$ aliquots containing either $0.2 \mathrm{ml} \mathrm{Kveim} \mathrm{material}(250 \mu \mathrm{g} / \mathrm{ml}$ as measured by protein content) or $0.2 \mathrm{ml}$ of the normal spleen suspensions. After 72 hours the supernatants were removed and duplicates pooled. The supernatants were equilibrated by the addition of $0.2 \mathrm{ml}$ Kveim material to the control tubes and $0.2 \mathrm{ml}$ normal spleen to the experimental tubes. All tests were performed in duplicate and some in triplicate, depending on the number of lymphocytes available after cell separation.

\section{ASSAY FOR MIGRATION INHIBITION FACTOR}

Macrophages were obtained from unsensitized guinea-pigs by inoculating $20 \mathrm{ml}$ of Eagle's medium (containing $5 \mathrm{iu} / \mathrm{ml}$ heparin) intraperitoneally and withdrawing the fluid after 10 minutes. The cells were washed three times in Eagle's medium and transferred to capillary tubes at a concentration of approximately 2 million cells per tube. After centrifugation and cutting within the cell containing part these were placed in Mackaness-type chambers (two per chamber) and the reconstituted supernatants added. The migration areas were measured after 48 hours by planimetry and the results expressed as the migration index $(\mathrm{MI})$, where $\mathrm{MI}=\frac{\mathrm{Ax}}{\mathrm{Ac}}, \mathrm{Ax}=$ migration area in chambers containing supernatant from lymphocyte cultures with Kveim material, Ac = area, as above cultured with normal spleen. The test takes five or six days.

\section{Results}

In the 30 sarcoid patients tested with Kveim material (Fig. 1), the Kmif test was positive (migration index less than $0 \cdot 8)$ in $21(70 \%$ ) compared with one positive test (a subject with no relevant past history or clinical evidence of disease) in 16 normal control subjects $(\mathrm{P}<0.005)$.

Steroid therapy influenced the results; four of five subjects on steroids had a negative Kmif test and in one patient tested before and during steroid therapy the $\mathrm{Kmif}$ test changed from positive to negative.

The relationship of the Kmif to the Kveim test, although using different lots of Kveim material, in 26 patients not on steroid therapy is shown in Table I. The Kmif test was positive in 20/26 (77\%)

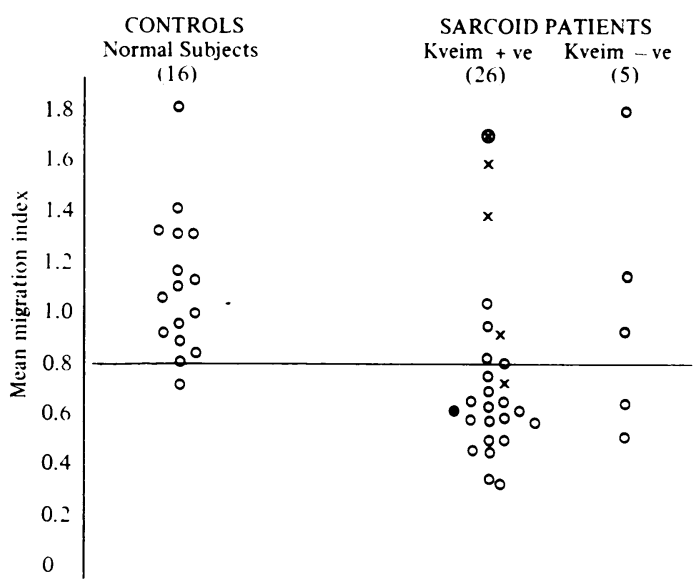

Fig. The results of Kmif testing in sarcoid and normal subjects. $O$ Patients not on steroid therapy; $X$ Patients on steroid therapy; $\otimes$ Patients tested before and during steroid therapy.

\begin{tabular}{lccc}
\hline Kmif Test & Kveim Test & \\
\cline { 2 - 4 } & - & 2 & \\
\hline- & 18 & 3 & 5 \\
\hline
\end{tabular}

Table I Correlation between in-vitro, Kmif, and in-vi Kveim tests in 26 patients not on steroids

and the Kveim test in $21 / 26(80 \%)$. In 21 of the 26 patients $(80 \%)$ the tests were in agreement. Of the five patients with discordant results, two were $\mathrm{Kmif}$ positive, Kveim negative, and three Kmif negative, Kveim positive.

It is noted that $\mathrm{Kmif}$ tests in the 26 non-steroid treated patients (Table II) are more frequently positive in those with disease radiologically localized to the hilar lymph nodes, those with a known

\begin{tabular}{llcl}
\hline & Category & No. & $\begin{array}{l}\text { Positive } \\
\text { Kmif Test }\end{array}$ \\
\hline \multirow{2}{*}{ Extent } & BHL = EN & 11 & 10 \\
Duration & Others & 15 & 10 \\
\multirow{2}{*}{ Tuberculin reaction } & $18 \mathrm{mth}$ & 14 & 12 \\
& Positive & 12 & 8 \\
& Negative & 6 & 5 \\
& Not known & 13 & 8 \\
& & 7 & 6 \\
\hline
\end{tabular}

Table II The relationship of Kmif testing to extent, duration, and tuberculin state of 26 sarcoid patients not on steroids

'BHL bilateral hilarlymphadenopathy, EN = erythema nodosum. 
duration of more than 18 months, and in patients with demonstrable cutaneous tuberculin sensitivity.

\section{Discussion}

Our results demonstrate that the Kmif test in vitro is a useful alternative to the cutaneous Kveim test.

Irrespective of age, the duration and extent of the disease, and the results of skin tests, the Kmif test was positive in $70 \%(21 / 30)$ of our series. This result is in close agreement with that, $71 \%(22 / 31)$, obtained by Becker et al (1972), using a different technique, the leucocyte migration test and their own antigen. These findings support the original observations of Hardt and Wanstrup (1969) using Hurley antigen (batch 0025 ), who showed a positive leucocyte migration test in all seven sarcoid patients tested. Topilsky et al (1972), using Siltzbach type I spleen $\mathrm{J}$ antigen, however, found no positive leucocyte migration test results in six subjects though they demonstrated by another technique that sarcoid lymphocytes show a higher spontaneous release of macrophage inhibition factor than controls and were uninfluenced by the addition of Kveim antigen. These divergent results, though few, may be due to the nature of the antigen. Caspary and Field (1971), using a complex electrophoretic macrophage mobility test, showed that sarcoid lymphocytes reacted not only with Kveim material (source unspecified) but also with other antigens, including neural tissue extracts. Though these results are difficult to evaluate the authors showed that lymphocytes from Mantouxdepressed or -negative sarcoid patients responded to tuberculo-protein in vitro and suggested the possibility of a 'depressing factor in sarcoid serum'. Although we could not establish a correlation between positive $\mathrm{Kmif}$ tests and negative Mantoux reaction such a mechanism may explain our finding in two patients with positive $\mathrm{Kmif}$ tests and negative Kveim tests. We are currently testing this hypothesis.

Our results confirm the findings of Becker et al (1972) and of Goldstein, Janick, and Schultz (1972) who showed that the leucocyte migration test is more often positive in patients with hilar lymphadenopathy than in those with more extensive disease and is thus similar to the results of Kveim testing. We also confirm the somewhat surprising finding of Becker $e t$ al that the test is more often positive in patients with a longer rather than a shorter history, which is at variance with the results of Kveim testing.

As in the Kveim test (Siltzbach and Waraich, 1969), steroid treatment considerably influenced our results. Three of the five $\mathrm{Kmif}$-negative subjects were on steroids and in one case retesting while on steroid treatment showed a reversal of the test from positive to negative. This is in agreement with the findings of Willoughby and Mitchell (1971) who used Kveim antigen in the leucocyte migration test in a series of patients with Crohn's disease.

We have found a good correlation in subjects not on steroids between the Kmif and Kveim test $(80 \%$ concordance) which agrees with earlier reportsseven out of seven (Hardt and Wanstrup, 1969) and 12 out of 13 (Becker et al, 1972). Despite a careful search we have no technical or clinical explanation for our five discordant results which were evenly distributed between the two tests and this must await testing of larger numbers. Excluding steroid therapy, the overall percentages of positive patients were similar with both tests, namely, Kmif $77 \%$ and Kveim $80 \%$, and using both tests $90 \%$.

The Kmif test, like the Kveim test, is unfortunately not specific for patients with sarcoidosis. We have found (unpublished) positive tests in two of seven cases with parenchymal pulmonary tuberculosis and five of 30 cases with Crohn's disease.

Brostoff and Walker (1971), using the same unphenolized Kveim material as ourselves, found that $47 \%$ of patients with Crohn's disease showed leucocyte migration inhibition, and they obtained consistently negative results in 24 patients with idiopathic proctocolitis. Further, Brostoff and Walker, in contrast to our findings, found that positive tests were unrelated to the severity of the disease and to corticosteroid therapy.

Caspary and Field (1971) have shown macrophage mobility inhibited in two patients with Crohn's disease, using sarcoid spleen suspensions from an unstated source. Willoughby and Mitchell (1971) and Pagaltsos, Kumar, Parneen, Willoughby, and Dawson (1971) have also reported positive tests in intestinal disease-12 of 18 in Crohn's disease and four of 10 in coeliac disease - and also a very high incidence in dermatitis herpetiformis (16 of 17 cases). Becker et al (1972) reported positive results in one of five patients with tuberculosis, six of 19 cases of Hodgkin's disease, and three out of three patients with 'collagen' disease. With the exception of those of Brostoff and Walker (1971), these divergent results may be due to the use of different Kveim spleen material, a problem which also confuses the cutaneous Kveim test, and will only be solved by the isolation of the active fraction. A second explanation is that of differences in technique, as the above authors have used the leucocyte migration test. We consider that our indirect technique, which prevents contact of the antigen with the indicator migrating cell, is preferable, especially when one is dealing with a coarse particulate antigen. The dose of antigen is also of considerable importance. It is likely that the negative results of Topilsky et al (1972) are due to their use of small concentrations, $8 \mu \mathrm{g}$ per $\mathrm{ml}$ as 
compared to our $250 \mu \mathrm{g}$ per $\mathrm{ml}$, and that of Becker et al (1972) who used $70 \mu \mathrm{g}$ per $\mathrm{ml}$.

Positive in-vitro Kveim tests have also been previously reported in normal subjects. Becker et al (1972) found two positive tests in 10 subjects. Our one positive case, a man aged 24, was Mantoux negative (10 TU), Kveim negative, and showed no clinical or radiological evidence of sarcoidosis or other disease and no relevant past history. The test will be repeated on this subject to exclude the interesting possibility of future development of sarcoidosis.

Despite these shortcomings, the Kmif test constitutes a rapid method of Kveim testing, obviates the necessity for biopsies, and avoids dispute in histological interpretation, in particular the danger occasioned by the presence of foreign bodies when sections are read by inexperienced observers.

The development of in-vitro tests of cellular immunity (Glade, Broder, Grotsky, and Hirschhorn, 1971) provides exciting possibilities for the future investigation of potential antigens, sensitivity states, and diagnosis of disease.

We wish to thank our colleagues in Sully Hospital, Cardiff Royal Infirmary, Bridgend Hospital, and the Cardiff and Newport chest clinics for their cooperation and access to clinical material.

\section{References}

Becker, F. W., Krull, P., Deicher, H., and Kalden, J. R. (1972). The leucocyte migration test in sarcoidosis. Lancet, 1, 120-123.
Bendixen, G., and Søborg, M. (1969). A leucocyte migration technique for in-vitro detection of cellular (delayed type) hypersensitivity in man. Dan. med. Bull., 16, 1-6.

British Medical Journal (1971). The Kveim test, Brit. med. J., 2, 604. Brostoff, J., and Walker, J. G. (1971). Leucocyte migration inhibition with Kveim antigen in Crohn's disease. Clin. exp. Immunol., 9, 引: 707-711.

Caspary, E. A., and Field, E. J. (1971). Lymphocyte sensitisation in sarcoidosis. Brit. med. J., 2, 143-145.

Chase, M. W. (1961). The preparation and standardisation of Kveim testing antigen. Amer. Rev. resp. Dis., 84, 86-88.

Dolby, A. E. (1969). Recurrent aphthous ulceration. Effect of sera and $\vec{D}$ peripheral blood lymphocytes upon oral epithelial tissue culture@ cells. Immunology, 17, 709-714.

Glade, P. R., Broder, S. W., Grotsky, H., and Hirschhorn, K. (1971). In-vitro Methods in Cell-Mediated Immunity, edited by B. R. $\overrightarrow{0}$ Bloom and P. R. Glade, pp. 307-310. Academic Press, New York, and London.

Goldstein, R. A., Janick, B. W., and Schultz, K. E. (1971). The Kveim $\vec{\omega}$ controversy. Lancet, 2, 1204.1205.

Hardt, F., and Wanstrup, J. (1969). Sarcoidosis: an in-vitro Kveim reaction based on the leucocyte migration test. Acta path. microbiol. scand., 76, 493-494.

Jones Williams, W., (1971). The Kveim controversy. Lancet, 2, 926- G 927.

Lancet (1971). The kneim controversey. Editorial. Lancet, 2, 750-751.

Lancet (1972). Kneim-Siltzback test vendicated Editorial. Lancet, 1 o 188.

Pagaltsos, A. S., Kumar, P. J., Willoughby, J. M. T., and음 Dawson, A. M. (1971). In-vitro inhibition of leucocyte migration by sarcoid spleen suspension in coeliac disease and $\vec{Z}$ dermatitis herpetiformis. Lancet, 2, 1179-1181.

Scadding, J. G. (1971). The Kveim controversy. Lancet, 2, 1372-1373.

Scadding, J. G. (1972). The Kveim reaction. Lancet, 1, 260.

Siltzbach, L. E., and Waraich, B. A. (1969). Effects of corticosteroid therapy on Kveim reactivity in Sarcoidosis. Amer. Rev. resp. 음 Dis., 99, 614-616.

Søborg, M., and Bendixen, G. (1967). Human lymphocyte migration $\overrightarrow{0}$ as a parameter of hypersensitivity. Acta med. scand., $18, \mathrm{~V}$ 247-256.

Topilsky, M., Siltzbach, L. E., Williams, M., and Glade, P. R. (197 Lymphocyte response in sarcoidosis, Lancet, 1, 117-120.

Willoughby, J. M. T., and Mitchell, D. N. (1971). In-vitro inhibition $\overline{6} f$ leucocyte migration in Crohn's disease by a sarcoid spleen suspension. Brit. med. J., 3, 155-157. 